\title{
The role of the legislative and regulatory branches in promoting the use of geothermal energy in Latvia
}

\author{
I. Skapare ${ }^{1}$, A. Kreslins ${ }^{1}$, and A. Cers ${ }^{2}$ \\ ${ }^{1}$ Institute of Heat, Gas and Water Technology, RTU, P.O. Box 526, Riga, 1010, Latvia \\ ${ }^{2}$ Latvenergo AS, P.O. Box 526, Riga, 1010, Latvia \\ Correspondence to: I. Skapare (inara312@inbox.lv), A. Kreslins (andris.kreslins@rtu.lv)
}

Received: 3 June 2015 - Revised: 7 October 2015 - Accepted: 10 November 2015 - Published: 27 September 2016

\begin{abstract}
Latvia currently is self-sufficient in energy resources up to approximately $35 \%$. Annual fossil energy prices rise and risks of security of energy supply promote the development legislation in the matter of renewable resources. One of the Latvian Ministry of Economics' recent products is a new draft law called the "Renewable Energy Law", which has been created due to one of the European Union and Latvian national energy policy objectives: to increase the share of renewable energy up to $40 \%$ by 2020 (Moore and Vanags, 2012). Currently, geothermal energy potential is assessed at $1 \times 1013 \mathrm{kWh}$; nevertheless, it is difficult for geothermal energy to compete with other renewable energy resources in the Latvian energy market. A great job has been done in recent years at the legislative branch to choose the right methods for supporting the use of renewable energy resources. This paper aims is analysis of current situation and assessment of Latvian legislation possibilities to promote the use of geothermal energy.
\end{abstract}

\section{Introduction}

Considering the increasing economic growth, the need for energy will increase in coming years; therefore, development and use of renewable energy sources, particularly geothermal energy, is vital.

The available primary energy sources in Latvia are the following: hydroelectricity (from the river Daugava), natural gas (thermo-electric stations, including cogeneration type), oil products (mainly for transport), peat and renewable energy resources (wind, sun, biogas, wood, geothermal energy).

At present, in Latvian circumstances, geothermal energy is not competitive, comparing to other types of renewables like hydroelectricity and biomass. As technology is maturing, however, this resource has a future, considering the ground potential and stability of the resource.

The biggest problem is that it takes big investments to harness geothermal energy, it has a long and difficult payoff time, compared to fossil fuels, and it is related to different technical risks.
For now, it is planned that the political basics in the field of energy will be focused on the increase of the safety and stability of the national energy supply. It means the following:

- an increase the amount of total consumption of local energy resources;

- an effective use of energy resources, support of the development of energy systems, and the implementation of energy efficient technology and energy saving;

- a continuous reduction of the damage to environment and a reduction of the amount of harmful emissions (Latvijas ilgtermina ekonomiska strategija, 2001).

\section{Current situation and problems}

In the European Union there is no united geothermal energy and no other policies promoting renewable resources consumption. Support strategies are not harmonized among the member states. The situation of member states and the potential of economically used resources are different; each country has its own policy to support renewable resources. It is not 
always simply considered as similar or different, if we compare to the situations of other previously mentioned member states and also due to different branches of state welfare.

In Latvia, by the special regulations in control over renewable energy area are known as the "Energy Law" and the "Electric Energy Market Law". According to these laws, the cabinet regulation No. 262 "Regulations of electric energy production by using renewable energy resources, and determination of pricing order", as well as the law "Of the regulators of public services" and its related regulations, as issued by the cabinet are relevant.

Although the base of legislative regulation is developed, which has created preconditions for the use of geothermal energy, it is necessary to develop and constantly evaluate the effectiveness of the national renewable resources policy and the support mechanism that is included in it, emphasizing the importance of geothermal energy in the development of national energy policy, the necessity to increase self-sufficiency of the capacity of energy and reduce the amount of imported energy resources, the reduction of Latvian energy dependence and the promotion of effective use of energy resources.

The Latvian economic development potential and competitiveness is also determined by the situation of energy supply system, its operational efficiency and security of supply. In recent years, the Latvian national electric energy consumption gross, in comparison to 2000, significantly increased (Pigens and Kampars, 2011).

Economic crisis has affected the entire Latvian economy, including energy fields; therefore, there is a significant change in the prognosis in energy resources consumption that has to be taken into consideration when evaluating the average time for documentation of policy planning and updating the newest prognosis of economic development.

It can be concluded that the policy of renewable energy, which is determined by Latvian average time for planning documents, regulations in that area and the regulations of the cabinet on support of energy production from renewable energy resources, considering the trends of economic growth, is insufficiently flexible to reach the goals for next years.

Upon evaluation of the directive of European Parliament and Council 2009/28/EC on promoting the use of renewable energy resources, it becomes clear that there is a reason to argue that the goals set for 2020 are ambitious enough.

To reach the goals set in Directive 2009/28/EC, there is still need for constant support mechanisms from the state that promote the use of energy obtained from renewable resources, keeping investors' trust.

Regarding development of the policy of renewable energy, BEMIP (Baltic Energy Market Interconnection Plan) has to be taken into consideration. It is signed by the heads of Baltic regional governments, including the heads of governments of the Baltic states, and is approved by the European Commission. BEMIP aims to deliver united regulations for all participants of the electric energy market of the three Baltic states in order to reach the BEMIP goal: the integration of the Baltic
Table 1. Implementation of the Renewable Energy Directive, (EU $20 \%$ target for renewable energy share (RES) for gross final energy consumption), Directive 2009/28/EC of 23 April 2009, Optional overview of progress towards the 1st interim target* (according to progress report of 27 March 2013, Energy challenges and policy, 2013).

\begin{tabular}{lllll}
\hline Member State & $\begin{array}{l}\text { 2005 RES } \\
\text { share, } \%\end{array}$ & $\begin{array}{l}\text { 2010 RES } \\
\text { share, } \%\end{array}$ & $\begin{array}{l}\text { 1st interim } \\
\text { target, } \%\end{array}$ & $\begin{array}{l}\text { 2020 RES } \\
\text { target, \% }\end{array}$ \\
\hline Austria $^{\mathrm{a}}$ & $23.3^{\mathrm{a}}$ & $30.1^{\mathrm{a}}$ & $25.4^{\mathrm{a}}$ & $34^{\mathrm{a}}$ \\
Germany $^{\mathrm{a}}$ & $5.8^{\mathrm{a}}$ & $11.0^{\mathrm{a}}$ & $8.2^{\mathrm{a}}$ & $18^{\mathrm{a}}$ \\
Estonia $^{\mathrm{a}}$ & $18^{\mathrm{a}}$ & $24.3^{\mathrm{a}}$ & $19.4^{\mathrm{a}}$ & $25^{\mathrm{a}}$ \\
Lithuania $^{\mathrm{a}}$ & $15^{\mathrm{a}}$ & $19.7^{\mathrm{a}}$ & $16.6^{\mathrm{a}}$ & $23^{\mathrm{a}}$ \\
Sweden $^{\mathrm{a}}$ & $39.8^{\mathrm{a}}$ & $49.1^{\mathrm{a}}$ & $41.6^{\mathrm{a}}$ & $49^{\mathrm{a}}$ \\
Latvia $^{\mathrm{c}}$ & $32.6^{\mathrm{c}}$ & $32.6^{\mathrm{c}}$ & $34.0^{\mathrm{c}}$ & $40^{\mathrm{c}}$ \\
UK $^{\mathrm{b}}$ & $1.3^{\mathrm{b}}$ & $3.3^{\mathrm{b}}$ & $4.0^{\mathrm{b}}$ & $15^{\mathrm{b}}$ \\
EU $^{\mathrm{b}}$ & $8.5^{\mathrm{b}}$ & $12.7^{\mathrm{b}}$ & $10.7^{\mathrm{b}}$ & $20^{\mathrm{b}}$ \\
\hline
\end{tabular}

${ }^{\mathrm{a}}>2 \%$ above interim target; ${ }^{\mathrm{b}}<1 \%$ from or $<2 \%$ above interim target; ${ }^{\mathrm{c}}>1 \%$ below interim target

energy market into the mutual European Union energy market.

According to Directive 2009/28/EC I annex, the Latvian goal is to increase the use of renewable resources from $32.6 \%$ in 2005 to $40 \%$ in 2020 of gross final energy consumption (Pigens and Kampars, 2011).

Provisional interim optional results (23 April 2013) are not satisfactory for the goal, comparing to other European countries (Table 1).

In the coming years, the Latvian Ministry of Economics is required to do the following: implement a mutual project of the member states of the European Union that provides for the creation of a renewable energy plant, which has been put into service or increased capacity of energy set in renewable energy plant after 25 January 2009. Private businesses may participate in this project.

Unfortunately, during previous years, there were no significant investments in geothermal energy, except shallow geothermal energy utilization (heat pumps). Therefore, society and potential investors are uncertain if projects of this nature could be feasible and profitable in Latvian circumstances. The main idea would be to realize the pilot deep geothermal project under the supervision of the Latvian Ministry of Economics with the following analysis of results, and to see if they are mostly positive, with wide-spread outreach in mass media.

Figure 1 shows the operating algorithm to run such a project.

One of the main parts of this algorithm is a feasibility study, because it shows what kind of projects would be most feasible given Latvian economic, political, geological and social conditions. 


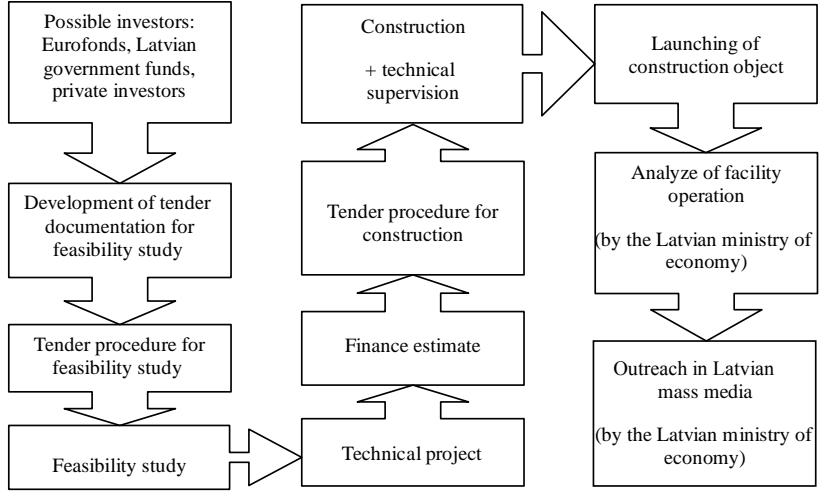

Figure 1. Operating algorithm for the deep geothermal pilot project.

\section{The state department's rights, obligations and main objectives}

The Latvian Ministry of Economics and regional governments have one of the main roles in promoting the use of geothermal energy. Renewable energy draft law provides the following national regulation:

\subsection{Functions of the Ministry of Economics}

To reach the goal set for 2020, the Ministry of Economics must do the following:

- create and supervise a renewable, including geothermal, energy summary system with the goal of assuring the control of states' goal consummation and performance that includes the following:

a. national-action-plan preparation in the field of geothermal energy;

b. national-action-plan clarification in the field of geothermal energy, if national goal is not reached;

- collect all the information in its possession about the events that have been implemented to promote the use of renewable energy, and based on that, analyze a national action plan in the field of renewable energy as well as its execution in the process of reaching the national goals;

- provide public with European Union's and international institutions' information on geothermal energy production and the realization of usage-promoting events in Latvia, summarize and update it on regular basis at least once every 6 months;

- develop an action plan in the field of geothermal energy, sample for regional governments and post it on their home page.

\subsection{Regional governments objectives in the field of geothermal energy}

Local regional governments within their competence, determined by regulations of regional governments regulatory performance, in territorial and detailed plan (if it is mandatory according to regulations), must include the planned amount and location of geothermal energy plants.

According to the regional governments action plan in the field of renewable energy, developed by Ministry of Economics, the sample local regional government develops a regional-government action plan in the field of renewable energy or includes planned actions in the field of renewable energy for said regional government's development program, and submits it to the Ministry of Economics. The regional government submits their plan to the Ministry of Economics regarding information on the use of renewable energy and the execution of the action plan in the territory of the regional government.

If the regional government according to mentioned action plan in the field of renewable energy is planning to provide support for renewable energy production, including local and individual heat supply, its self-consumption, in the household sector and to individual people, then the regional government must issue mandatory regulations and create support receivers with the duty of accounting for the amount of produced and used energy.

Regional government coordinates corresponding support provided by the Ministry of Economics in case its necessity is determined by regulations in the field of business support control. Regional government then informs the Ministry of Economics on providing support (Neimane, 2011).

\section{Most important articles of the renewable energy draft law}

At the end of 2010, the Ministry of Economics submitted a draft law for a review to Latvian parliament. At the first Parliament meeting the draft law was supported, although later it was concluded that it has to be significantly improved. Unfortunately it seems like the work on this is stopped because the law has still not been accepted. Even though renewable energy usage promoting events offered by the draft law would be urgent for national energy.

\subsection{Renewable energy usage promoting events \\ 4.1.1 Provided financial tools for renewable energy usage promotion}

For promoting the usage of renewable energy, national or regional governments can provide several tools: the financial tools of individual people (funds, subsidies, tax discounts, mortgages, funding provided by a third person, energy purchase agreement and other tools), as well as direct strategies 
for price support, and other events that are determined according to tax laws, laws of public purchase, regulations of rates, crediting, state security and other fields promoting the consummation of national goals determined by this law.

Provided tools for promoting renewable energy usage are as follows:

1. diversion of state given financing to renewable electric energy production and consumption, including energy production equipment in which fossil energy resources are used; transformation to equipment in which renewable energy resources are used (excluding an equipment change in energy production in which fossil energy resources are used that were created, installed and have had their supported in any way until the day when this law becomes effective;

2. additional payment, which includes power components, greenhouse gas components and agriculture components, for electric energy, produced from renewable resources;

3. a public dealer with the duty of purchasing renewable electric energy from a renewable energy plant located by the Republic of Latvia, which has electric energy set less than 2 megawatts, or its connected companies (all plants in their possession or use in which electric power is set to less than 2 megawatts);

4. support for renewable energy plant, which set power is less than 5 megawatts, connection to electric energy network;

5. support for research, development and innovation programs in the field of renewable electric energy;

6. interstate co-operation events;

7. renewable-electric-energy-usage promotion events, set by other regulations, aimed towards reducing the costs of renewable energy.

Renewable heat energy and cooling usage promoting financing tools are planned as follows:

1. state-provided financial aid for the consumption of renewable heat energy, including energy production equipment, in which fossil energy resources are used; transformation to equipment, in which renewable energy resources are used (excluding an equipment change in energy production in which fossil energy resources are used that were created, installed and have had their performance supported in any way until the day when this law becomes effective);

2. support for research, development and innovation programs in the field of renewable heat energy;

3. renewable-heat-energy-usage promotion events, set by other regulations, oriented on reducing the costs of renewable energy.

\subsubsection{Additional payment for electric energy}

The renewable energy producer has the right to additional payment, which produces electric energy in the territory of the Republic of Latvia, in the Republic of Latvia territorial sea, in the Republic of Latvia's exclusive economic zone in the continental shelf, for produced and sold renewable electric energy in the electric energy market. If a renewable energy plant, which produces electric energy in an effective cogenerated process, uses other fuel types, resulting in less than $10 \%$ of the plant's used fuel, then all of that plant's produced electric energy is considered to be obtained from renewable energy resources (Neimane et al., 2011).

\section{Conclusions}

Unfortunately, because of its economic situation, Latvia cannot afford to provide sufficient financial support (subsidies) to geothermal energy use. However, considering fast growing energy prices, perhaps it is worth putting certain financing into the development of renewable resources, including geothermal energy on the scale of the state.

To promote the use of geothermal energy in Latvia at legislative and regulatory branches, first, it would be necessary to include in new "RES law" that during planning of Latvian annual budget, certain financial support for RES should be included, with detailed distribution for each type of renewable energy source.

Based on other European countries' experience, it is necessary to emphasize that geothermal projects (in the first year) will receive comparatively significant subsidies, but the annual amount of subsidies will be reduced. Thus, the use of geothermal energy will be maximally accelerated during first few years.

Geothermal energy usage types without subsidies also would be effective, such as the integration of a request in legislation requiring the building of new structures or energy supply systems in existing buildings. In such a scenario, it would be necessary to foresee that a certain percent of energy used for the needs of the building will be from renewable energy resources, including geothermal sources. However, in this case, it has to be taken into consideration, that it could create a price rise of new building construction and existing building reconstruction, which in turn could reduce the amount of construction.

An existing support mechanism for renewable resources usage is basically planned for electric energy production, which in turn cannot help in usage cases characteristic of heat energy and geothermal water balneology, which in turn in Latvian circumstances today looks the most probable scenario (Skapare and Kreslins, 2010).

To increase the interest of investors in deep geothermal energy projects and their profitability, it would be necessary to financially support and execute the deep geothermal energy 
pilot project. If it is not considered in the Latvian budget, perhaps funds from the European Union could help.

Acknowledgements. I am very thankful to the referees and editor.

Edited by: H. Rüter

Reviewed by: D. Chandrasekharam and one anonymous referee

\section{References}

Energy challenges and policy: Commission contribution, to the European Council of 22 May 2013.

Latvijas ilgtermina ekonomiska strategija, http://likumi.lv/doc.php? id=55125 (last access: 26 September 2016), 2001.
Moore, I. and Vanags, A.: Expert evaluation network delivering policy analysis on the performance ofcohesion policy 2007-2013 year 1-2011; Task 1: Policy paper on renewable energy and efficiency of residential, 2012.

Neimane, B., Stepanovs, K., and Kampars, A.: "Atjaunojamas energijas likums", Projekts, ("RES low", Project), Latvian Ministry of Economics, http://www.mk.gov.lv/lv/mk/tap/?pid=40190380 (last access: 26 September 2016), 2011.

Pigens, K. and Kampars, A.: Likumprojekta "Atjaunojamas energijas likums" ("RES low") sakotnejas ietekmes novertejuma zinojums (anotacija), Latvian Ministry of Economy, http://www. mk.gov.lv/lv/mk/tap/?pid=40190380 (last access: 26 September 2016), 2011.

Skapare, I. and Kreslins, A.: Research of Available Mineral Geothermal Water Resources for Utilization in Latvian Sanatoriums, Proceedings of WGC 2010, 2010. 